\title{
Microgram per Kilogram per Hour
}

National Cancer Institute

\section{Source}

National Cancer Institute. Microgram per Kilogram per Hour. NCI Thesaurus. Code

C73730.

A dose calculation unit expressed in microgram(s) per kilogram per period of time equal to sixty minutes. 